\title{
THE BOEING DECISION: A BLOW TO FEDERALISM, INDIVIDUAL RIGHTS AND STARE DECISIS
}

\author{
Charles B. Graver $\dagger$
}

\section{INTRODUCTION}

In 1947, the Taft-Hartley Act ${ }^{1}$ amended the National Labor Relations Act (NLRA) ${ }^{2}$ by promulgating a code of unfair labor practice regulations which pertained to labor organizations. ${ }^{3}$ One of these new provisions, section $8(\mathrm{~b})(1)(\mathrm{A}),{ }^{4}$ prohibited unions from restraining or coercing employees in the exercise of rights guaranteed them under the NLRA. ${ }^{5}$ Soon after

† Lecturer in Law, University of California at Berkeley. B.S. 1967, M. Ind. \& Lab. Rel. 1968, Cornell University; J.D. 1971, University of Michigan. Member, California Bar.

${ }^{1}$ Act of June 23, 1947, ch. 120, Pub. L. No. 80-101, 61 Stat. 136.

249 Stat. 449 (1935), as amended, 29 U.S.C. $\$ \$ 150$ et seq. (1970) (Wagner Act).

${ }^{3}$ Prior to the 1947 amendments to the NLRA, only the conduct of employers was restricted by the federal labor statute.

429 U.S.C. $\$ 158(\mathrm{~b})(1)(\mathrm{A})(1970)$, which provides:

(b) It shall be an unfair labor practice for a labor organization or its agents-

(1) to restrain or coerce (A) employees in the exercise of the rights guaranteed in section 157 of this title: Provided, That this paragraph shall not impair the right of a labor organization to prescribe its own rules with respect to the acquisition or retention of membership therein . . . .

Concerning the rights protected by the NLRA, see note 5 infra. For the statutory definition of "employee," see 29 U.S.C. § 152(3) (1970).

${ }^{5}$ Section 7 of the NLRA, 29 U.S.C. $\S 157$ (1970), which defines the scope of guaranteed rights, provides:

Employees shall have the right to self-organization, to form, join, or assist

labor organizations, to bargain collectively,through representatives of their own choosing, and to engage in other concerted activities for the purpose of collective bargaining or other mutual aid or protection, and shall also have the right to refrain from any or all of such activities except to the extent that such right may be affected by an agreement requiring membership in a labor organization as a condition of employment as authorized in section 158(a)(3) of this title.

Section 8(a)(3), 29 U.S.C. \$ 158(a)(3) (1970), permits a labor organization and an employer to enter into a collective bargaining agreement which contains a union-security provision requiring employees to become union members within a specified period of time as a condition of continued employment. For the text of $\$ 8(a)(3)$, see note 114 infra. But see Union Starch \& Refining Co., 87 N.L.R.B. 779 (1949), enforced, 186 F.2d 1008 (7th Cir.), cert. denied, 342 U.S. 815 (1951) (employees may not be discharged pursuant to a valid union-security provision so long as they merely tender their union dues and fees, although they refuse to attend union meetings or take a membership oath). See Toner, The Union Shop Under Taft-Hartley, 5 LAB. L.J. 552 (1954); 52 Мгсн. L. Rev. 619 (1954). This statutory interpretation was expressly approved by the Supreme Court in NLRB v. General Motors Corp., 373 U.S. 734 (1963), in which the Court noted that "[M]embership, insofar as it has significance to employment rights, may ... be conditioned only upon payment of fees and dues. 'Membership' as a condition of employment is whittled down to its financial core." 373 U.S. at 742. This statutory construction was based upon legislative history indicating that Congress was concerned only with preventing employees from deriving substantial benefits from union representation without having to 
the enactment of this section, Professor Cox predicted future interpretative difficulties:

Section 8(b)(1) may plunge the [Labor] Board into a dismal swamp of uncertainty. Its vagueness alone, not to mention the broad interpretations put upon it during the debates in Congress, encourages the filing of great numbers of [unfair labor practice] charges as weapons in fighting the unionization of a plant. A long period of uncertainty and heavy volume of litigation will be necessary before the questions of interpretation can be resolved. ${ }^{6}$

This prophetic evaluation has certainly proved correct with respect to union discipline of members.

In the recent Boeing decision, ${ }^{7}$ the Supreme Court held that where a labor organization imposes an otherwise valid disciplinary fine upon one of its members, it is not the obligation of the National Labor Relations Board to evaluate the reasonableness of the amount of that fine, since this issue is not relevant to a section $8(b)(1)(A)$ unfair labor practice charge. This article will examine that opinion in light of both the congressional intent underlying the pertinent Taft-Hartley amendments and the implications which can be derived from prior Supreme Court pronouncements pertaining to union disciplinary action. Since the writer disagrees with the conclusion reached by the Supreme Court, an alternative approach will be suggested, and the ramifications of this contrary approach will be analyzed, in an effort to assuage the concerns underlying the Supreme Court's evaluation. However, before dealing specifically with the Boeing decision's reasonableness question, it will be useful to summarize briefly the general principles regarding the legality of union discipline.

\section{General Propriety of Union Discipline}

Although the NLRA did not impose any restrictions upon union activity until $1947,{ }^{8}$ the discipline of union members by

accept any of the financial obligations of union membership. See Radio Officers' Union v. NLRB, 347 U.S. 17, 40-42 (1954). See also Evans v. American Fed'n of 'Television Artists, 354 F. Supp. 823 (S.D.N.Y. 1973) (concerning the right of a union to require membership by television and radio commentators in light of first amendment considerations). (1947).

${ }^{6}$ Cox, Some Aspects of the Labor Management Relations Act, 1947, 61 HARv. L. REv. I, 33

'NLRB v. Boeing Co., 412 U.S. 67 (1973). Booster Lodge 405 of the International Association of Machinists was the labor organization involved.

${ }^{8}$ See notes $1-5$ supra \& accompanying text. 
labor organizations was not wholly unregulated. State courts had been adjudicating internal union disputes for over fifty years. ${ }^{9}$ However, such state court intervention was generally not pervasive. As Professor Summers' research indicated, ${ }^{10}$ most state courts did not demonstrate much antagonism to union discipline, as they upheld penalties for such activities as working during a strike ${ }^{11}$ or in a nonunion shop, ${ }^{12}$ working for substandard wages, ${ }^{13}$ or engaging in unauthorized strikes ${ }^{14}$ or misconduct on the job. ${ }^{15}$ Only in extreme cases was the union disciplinary action overturned. ${ }^{16}$

It is not difficult to understand the hesitancy of state tribunals to impose limitations upon the freedom of labor organizations to discipline their members for infractions of union rules.

Discipline is the criminal law of union government. It is the critical device for maintaining internal order, enforcing obligations of membership, and compelling adherence to union standards in employment. It strengthens the union as an effective bargaining representative and is essential for internal democracy. ${ }^{17}$

On the other hand, union discipline may "be used to stifle the democratic process by punishing those who criticize and retaliating against those who oppose." 18 Following the enactment of the NLRA, it became apparent that discipline could also be utilized to discourage members from exercising the rights provided them by that Act. Because of this, and particularly after the adoption of the Taft-Hartley amendments to the NLRA proscribing unfair labor practices by labor organizations, it became incumbent upon the Labor Board and the federal courts to define the permissible scope of union discipline in relation to the exercise of protected section 7 rights.

${ }^{9}$ Summers, The Làw of Union Discipline: What the Courts Do In Fact, 70 YaLe L.J. 175 (1960) [hereinafter cited as Courts]; see cases cited id. n.3. Regarding general union disciplinary practices, see P. TAFT, The Structure and Government of Labor UNions 117-80 (1954); Summers, Disciplinary Power of Unions, 3 IND. \& LAB. REL. REV. 483 (1950).

${ }_{10}$ Courts, supra note 9 , at $188-89$ \& nn. 70-75.

11 See, e.g., Havens v. King, 221 App. Div. 475, 224 N.Y.S. 193 (1927).

12 See, e.g., Schouten v. Alpine, 215 N.Y. 225, 109 N.E. 244 (1915); Watson v. Victory, 127 N.Y.L.J. 307 (Sup. Ct. 1952).

${ }_{13}$ See, e.g., Rubens v. Weber, 237 App. Div. 15, 260 N.Y.S. 701 (1932); Drazen v. Curby, 172 App. Div. 417, 158 N.Y.S. 507 (1916).

${ }^{14}$ See, e.g., Cromwell v. Morrin, 91 N.Y.S.2d 176 (Sup. Ct. 1949).

15 See, e.g., Austin v. Dutcher, 56 App. Div. 393, 67 N.Y.S. 819 (1900) (stealing); Perez v. Curran, File No. $3144 / 57$ (N.Y. Sup. Ct., N.Y. County 1957) (fighting on shipboard).

${ }_{16}$ See Summers, Legal Limitations on Union Discipline, 64 HARv. L. Rev. 1049, 1078, 1083-84 (1951).

${ }_{17}^{17}$ Courts, supra note 9 , at 178.

${ }^{18}$ Id. 


\section{A. Permissible Scope of Union Discipline Under the NLRA}

As early as 1954, in Minneapolis Star and Tribune Co., ${ }^{19}$ the Labor Board was called upon to decide whether a union violated section $8(\mathrm{~b})(1)(\mathrm{A})^{20}$ when it imposed a disciplinary fine upon a member because of his refusal to attend union meetings and engage in picket duty during a strike. ${ }^{21}$ In his intermediate report, the trial examiner emphasized the fact that the proviso to section $8(\mathrm{~b})(1)(\mathrm{A})$ expressly indicated that this section "shall not impair the right of a labor organization to prescribe its own rules with respect to the acquisition or retention of membership therein," and he concluded that the union disciplinary action did not violate the Act. ${ }^{22} \mathrm{He}$ reasoned that "Congressional recognition of a labor organization's right to make its own rules presumes, of course, its right to invoke them-except where the implementing of such rules is expressly prohibited, as in the case of affecting an employee's employment rights."23 The Labor Board accepted this analysis, as it cursorily concluded that "the proviso to Section $8(\mathrm{~b})(1)(\mathrm{A})$ precludes any such [NLRB] interference with the internal affairs of a labor organization."24

The Supreme Court did not become directly involved with union discipline until 1967, in NLRB v. Allis-Chalmers Manufacturing $C o{ }^{25}$ In Allis-Chalmers the court was required to determine whether a union violated section $8(\mathrm{~b})(1)(\mathrm{A})$ when it imposed disciplinary fines upon members who performed strikebreaking

19109 N.L.R.B. 727 (1954).

${ }^{20}$ For the text of $\S 8(\mathrm{~b})(1)(\mathrm{A})$, see note 4 supra.

21 The trial examiner indicated that his research had not disclosed any NLRB precedent in this area. 109 N.L.R.B. at 738.

${ }^{22} I d$.

${ }^{23}$ Id. It is clear that a labor organization may not lawfully utilize disciplinary action to affect the employment conditions or rights of the member in question. Section $8(a)(3)$ of the NLRA, 29 U.S.C. § 158(a)(3) (1970), prohibits an employer from discriminating against any employee on account of any union activity or lack of union activity-except for an employee's failure to tender his union dues and fees pursuant to a valid union-security provision in the applicable collective-bargaining agreement. Furthermore, $\S 8(b)(2), 29$ U.S.C. § 158(b)(2) (1970), prohibits a labor organization from causing or attempting to cause an employer to discriminate against any employee in violation of $\S$ $8(a)(3)$. For the text of $\S \S 8(a)(3)$ and $8(b)(2)$, see note 114 infra. It is therefore established that a union may not enforce any disciplinary action against a member, except where such action relates to the member's failure to tender the requisite dues and fees pursuant to a valid union-security agreement, by inducing or attempting to induce the employer to discriminate against the employee in regard to employment conditions. See, e.g., Electric Auto-Lite Co., 92 N.L.R.B. 1073 (1950), enforced per curiam, 196 F.2d 500 (6th Cir.), cert. denied, 344 U.S. 823 (1952).

${ }^{24} 109$ N.L.R.B. at 729. It is obvious that the Labor Board's conclusionary statement presumed the very answer it was actually called upon to provide. Although the proviso may well have indicated a congressional desire to avoid interference with truly internal affairs of labor unions, the NLRB's analysis failed to explain the distinction between internal and external concerns for $\$ 8(b)(1)$ (A) purposes-other than where employment rights were directly affected. See note 91 infra.

25388 U.S. 175 (1967). 
work during an economic strike. ${ }^{26}$ Although a divided Supreme Court upheld the right, under the NLRA, of a labor organization to impose such fines, it utilized reasoning which differed substantially from the rationale which had been used by the Labor Board in its Minneapolis Star decision. ${ }^{27}$

The Allis-Chalmers opinion noted that "[i]t is highly unrealistic to regard $\S 8(\mathrm{~b})(1)$, and particularly its words 'restrain or coerce,' as precisely and unambiguously covering the union conduct involved in this case," and concluded that "recourse to legislative history to determine the sense in which Congress used [those] words is not foreclosed."28 It emphasized that "labor legislation is peculiarly the product of legislative compromise of strongly held views . . . and that legislative history may not be disregarded merely because it is arguable that a provision may unambiguously embrace conduct called in question." 29 The Court then undertook a detailed analysis of the legislative history surrounding the enactment of the Taft-Hartley Act amendments to the NLRA, and it concluded that Congress did not intend to prohibit union disciplinary action against strikebreaking members by the prohibition against "restraint" or "coercion" contained in section $8(\mathrm{~b})(1)(\mathrm{A}) .^{30}$ However, the Court did not rely exclusively upon the legislative history.

The Allis-Chalmers majority found additional support for its interpretation of section $8(\mathrm{~b})(1)(\mathrm{A})$ in what it perceived to be the general policy considerations underlying the enactment of the NLRA in 1935. It noted:

National labor policy has been built on the premise that by pooling their economic strength and acting through a labor organization freely chosen by the majority, the employees of an appropriate unit have the most effective means of bargaining for improvements in wages, hours, and working conditions. The policy therefore extinguishes the individual employee's power to order his own relations with his employer and creates a

${ }^{26}$ The Allis-Chalmers situation differed from that in Minneapolis Star in that in the former the union instituted state court collection actions to enforce the disciplinary fines.

${ }_{27}$ Because of the analytical approach undertaken by the Supreme Court in AllisChalmers, it was not required to resolve the issue whether the proviso to $\S 8(\mathrm{~b})(1)(\mathrm{A})$ protected union disciplinary actions from being considered unfair labor practices. See 388 U.S. at 192 n.29.

${ }^{28} I d$. at 179 .

${ }^{29}$ Id. See National Woodwork Mfrs. Ass'n v. NLRB, 386 U.S. 612, $619-20$ (1967).

${ }^{30} 388$ U.S. at 183-95. For another detailed analysis of the legislative history pertaining to $\S 8(\mathrm{~b})(1)(\mathrm{A})$, see National Maritime Union, 78 N.L.R.B. 971, 982-87 (1948), enforced, 175 F.2d 686 (2d Cir. 1949), cert. denied, 338 U.S. 954 (1950). Regarding the questionable value of resort to legislative history in the interpretation of the congressional intent underlying $\$ 8(\mathrm{~b})(\mathrm{I})(\mathrm{A})$, see notes $93-113$ infra \& accompanying text. 
power vested in the chosen representative to act in the interests of all employees. 'Congress has seen fit to clothe the bargaining representative with powers comparable to those possessed by a legislative body both to create and restrict the rights of those whom it represents .....31

The majority further recognized:

Integral to this federal labor policy has been the power in the chosen union to protect against erosion its $[s i c]$ status under that policy through reasonable discipline of members who violate rules and regulations governing membership. That power is particularly vital when the members engage in strikes. The economic strike against the employer is the ultimate weapon in labor's arsenal for achieving agreement upon its terms, and ' $[t]$ he power to fine or expel strikebreakers is essential if the union is to be an effective bargaining agent . . . . ${ }^{32}$

In light of these strong policy considerations, the Allis-Chalmers majority decided that its interpretation of the congressional intent underlying section $8(\mathrm{~b})(1)(\mathrm{A})$ was correct. $^{33}$

In more recent decisions, the Supreme Court has reaffirmed the right of unions to impose and enforce reasonable fines against members who violate valid union regulations. In Scofield $v . N L R B,{ }^{34}$ the Court was presented with a situation in which a labor organization had attempted through state court actions to collect fines which it had imposed upon members who had violated a union rule relating to work production ceilings. The Court noted that under Allis-Chalmers and related Labor Board decisions, "[section] 8(b)(1) leaves a union free to enforce a properly adopted rule which reflects a legitimate union interest, impairs no policy Congress has imbedded in the labor laws, and is reasonably enforced against union members who are free to leave the union and escape the rule." 35 The Scofield Court con-

${ }^{31} 388$ U.S. at 180.

32 Id. at 181 .

${ }^{33}$ For an excellent critical evaluation of the Allis-Chalmers decision, see Christensen, Union Discipline Under Federal Law: Institutional Dilemmas in an Industrial Democracy, 43 N.Y.U.L. REv. 227, 264-78 (1968). See also Atleson, Union Fines and Picket Lines: The NLRA and Union Disciplinary Power, 17 U.C.L.A.L. Rev. 681 (1970); Gould, Some Limitations Upon Union Discipline Under the National Labor Relations Act: The Radiations of Allis-Chalmers, 1970 Duke L.J. 1067; Silard, Labor Board Regulation of Union Discipline After Allis-Chalmers, Marine Workers and Scofield, 38 GEO. WASH. L. REv. 187 (1969); Note, 53 CoRnELl L. REv. 1094 (1968); Comment, $8(b)(1)(A)$ Limitations upon the Right of a Union to Fine Its Members, 115 U. PA. L. Rev. 47 (1966).

34394 U.S. 423 (1969).

${ }^{35}$ Id. at 430 . 
cluded that since the union rule in question "left the collective bargaining process unimpaired, breached no collective contract, required no pay for unperformed services, induced no discrimination by the employer against any class of employees, and represent[ed] no dereliction by the union of its duty of fair representation," the enforcement of that rule by disciplinary fines did not violate section $8(\mathrm{~b})(1)(\mathrm{A}) .^{36}$

In NLRB v. Industrial Union of Marine Workers ${ }^{37}$ the Supreme Court also upheld the right of unions to impose discipline upon members for violations of legitimate union regulations which did not conflict with any specific federal labor policies: However, in that decision the Court expressly recognized that some limitations upon union disciplinary action do emanate from the NLRA.

\section{B. Limitations Upon Union Discipline Under the NLRA}

Although the Labor Board had previously recognized the existence of some substantive limitations upon union discipline under the NLRA, ${ }^{38}$ it was not until the Marine Workers decision that the Supreme Court provided its imprimatur to the NLRB's statutory interpretation. In Marine Workers, the Supreme Court upheld the Labor Board's determination that a labor organization violates section 8(b)(1)(A) when it expels a member for failing to exhaust all available internal union remedies before filing an unfair labor practice charge with the NLRB. The Court noted that while "[section] $8(\mathrm{~b})(1)(\mathrm{A})$ assures a union freedom of self-regulation where its legitimate internal affairs are concerned, . . . other considerations of public policy come into' play"39 when a union penalizes a member for filing an unfair labor practice charge. Under the circumstances presented in the Marine Workers case, the Court indicated that these public policy considerations included the necessity for free access to the Labor Board unimpeded by any union interference. ${ }^{40}$ The Court unfortunately did not delineate other areas in which policy considerations might impose restrictions upon the right of unions to discipline their members. Nevertheless, subsequent Labor Board decisions have provided some assistance in this regard.

${ }^{36} I d$. at 436.

37391 U.S. 418 (1968).

${ }^{38}$ See, e.g., Local 138, Operating Eng'rs, 148 N.L.R.B. 679 (1964) (labor organization violated $\S 8$ (b)(1)(A) by imposing a disciplinary fine upon a member for filing an unfair labor practice charge with the NLRB before exhausting internal remedies). The rationale of this opinion was expressly approved by the Supreme Court in Marine Workers.

39391 U.S. at 424 .

${ }^{40} \mathrm{Id}$. at $424-25$. 
In Local 12419, UMW, ${ }^{41}$ the NLRB held that a union violates section $8(\mathrm{~b})(1)(\mathrm{A})$ when it fines members for crossing a sister union's lawful picket line, where the contract in existence between the picketed employer and the labor organization imposing the discipline contained an applicable no-strike clause. Policy considerations favoring such no-strike arrangements were found to outweigh the right of a union to enforce its internal regulations. ${ }^{42}$ In a later 1969 decision, the NLRB was faced with an even more difficult balancing problem.

Four years earlier, in Tawas Tube Products, Inc., ${ }^{43}$ the Labor Board recognized the right of a labor organization to expel a member for having filed a decertification petition seeking to terminate the representative status of the union. ${ }^{44}$ However, in International Molders Local 125,45 another case involving union disciplinary action against a member for filing a decertification petition, the NLRB distinguished a disciplinary fine from an expulsion. It indicated the necessity "of reconciling the public policy of protecting access to the Board with a union's right to prescribe its own rules respecting 'the acquisition or retention of membership." "46 The Labor Board noted that

[i] $n$ the case of a decertification petition, the employee seeks to attack the very existence of the union as an institution, ${ }^{47}$ and unless the union can expel the member who seeks its destruction, "during the preelection campaign, the member could campaign against the union while remaining a member and therefore - privy to the union's strategy and tactics." 48

The NLRB therefore concluded that while "the union needs [the] power of expulsion in order to defend its status as bargaining representative," 49 it does not require the authority to fine a

41176 N.L.R.B. 628 (1969).

42 But see Machinists Lodge 284, 190 N.L.R.B. 208 (1971), enforced in part \& remanded for determination of reasonableness of fines, $472 \mathrm{~F} .2 \mathrm{~d} 416$ (1972) (upheld similar fines, based upon the fact that the no-strike agreement which existed between the picketed employer and the disciplining union specifically allowed employees to honor legitimate picket lines against that employer).

${ }^{43} 151$ N.L.R.B. 46 (1965).

44 The Labor Board's position was upheld in Price v. NLRB, 373 F.2d 443 (9th Cir. 1967), cert. denied, 392 U.S. 904 (1968).

45178 N.L.R.B. 208 (1969), enforced, 442 F.2d 92 (7th Cir. 1971).

${ }^{46} \mathrm{Id}$. at 208. The Molders decision is quite noteworthy, since it at least implicitiy recognized a distincoion for some purposes between expulsions, which fall within the literal language of the proviso to $\S 8(\mathrm{~b})(1)(\mathrm{A})$, and disciplinary fines, which do not. $C f$. Minneapolis Star \& Tribune Co., 109 N.L.R.B. 727 (1954).

${ }^{47}$ The Landrum-Griffin Act, 29 U.S.C. $\$ 411$ (a)(2) (1970), specifically recognizes "the right of a labor organization to adopt and enforce reasonable rules as to the responsibility of every member toward the organization as an institution ...."

${ }^{48} 178$ N.L.R.B. at 208.

${ }^{49} I d$. "In short, where the union member is seeking to decertify the union . . . the 
member who has filed a decertification petition, since a fine is merely punitive, and not, like expulsion, defensive. ${ }^{50}$ The union's imposition of a disciplinary fine upon the member in question was thus determined to constitute an $8(\mathrm{~b})(1)(\mathrm{A})$ violation. ${ }^{51}$

One other limitation upon the right of labor organizations to impose disciplinary fines should be noted. In the Granite State decision, ${ }^{52}$ the Supreme Court held that a union may only impose discipline upon persons who are actually members of that organization at the time the acts complained of are performed. ${ }^{53}$ Therefore, when a member effectively resigns from his union before engaging in activity contrary to the labor organization's rules, he may not lawfully be fined by that union. ${ }^{54}$

\section{The Reasonableness of Union Fines Under the NLRA}

Although the Labor Board and the Supreme Court have imposed several restrictions upon the right of labor organizations to fine their members for conduct violative of union obligations, they have both determined that the reasonableness of the amount of a fine is not relevant to the issue whether there is an unfair labor practice under the NLRA. Since this Article will be primarily concerned with the propriety of this position, it is necessary to examine carefully the evolution of this doctrine.

public policy against permitting a union to penalize a member because he seeks the aid of the Board should give way to the union's right to self-defense." Id. at 209.

${ }^{50} I d$. at 209. The NLRB also recognized that where a member has filed a decertification petition in an effort to eliminate the union as his bargaining representative, he has indicated such a lack of regard for his union membership that his expulsion from that organization would not effectively deter him from resorting to the Labor Board's processes. $I d$. at 208.

51 The Labor Board's decision was enforced by the Seventh Circuit, which accepted the NLRB's distinction between defensive and retaliatory disciplinary action. NLRB v. International Molders Local 125, 442 F.2d 92 (7th Cir. 1971). Accord, Tri-Rivers Marine Eng'rs Union, 189 N.L.R.B. 838, in which the Labor Board held that while an incumbent union violated the NLRA by imposing a fine upon a member for soliciting authorization cards in favor of an election petition by an outside labor organization, that same union did not violate the Act when it threatened to expel the disloyal member unless he paid the fine. See also Note, Union Disciplinary Power and Section $8(b)(1)(A)$ of the National Labor Relations Act: Limitations on the Immunity Doctrine, 41 N.Y.U.L. REv. 584 (1966).

${ }^{52}$ NLRB v. Granite State Joint Bd., Textile Workers Union, 409 U.S. 213 (1972).

${ }^{53}$ The Court did not decide upon the authority of a union to impose discipline upon an individual who was a "member" only to the extent of tendering his dues and fees without formally affirming his allegiance to the organization. Since collection actions are generally founded upon principles of contract law, it would be difficult to imagine a court enforcing a fine against an individual who never assented to the obligations contained in the union's by-laws and constitution, but only paid dues and fees pursuant to an enforceable union-security contract. This analysis is supported by the recognition of the Granite State Court that "the power of the union over the member is certainly no greater than the union-member contract." Id. at 217.

${ }^{5}$ Booster Lodge 405, IAM v. NLRB, 412 U.S. 84 (1973). See Note, 72 Colum. L. REv. 1272 (1972). 
The Labor Board was first called upon to determine the effect of the amount of a disciplinary fine upon a section $8(\mathrm{~b})(1)(\mathrm{A})$ complaint in Machinists, Lodge 504.55 A union member had been fined $\$ 500$ for working during an authorized economic strike, and the union had obtained a state court judgment against him for $\$ 528 .^{56}$ The member thereafter filed an $8(\mathrm{~b})(1)(\mathrm{A})$ charge alleging, inter alia, that the unreasonably large nature of the union's fine ${ }^{57}$ constituted a violation of the NLRA. The Labor Board emphasized "the repeated refrain throughout the [legislative] debates on $\S 8(\mathrm{~b})(1)(\mathrm{A})$ and other sections that Congress did not propose any limitations with respect to the internal affairs of unions, aside from barring enforcement of a union's internal regulations to affect a member's employment status." Congress nonetheless intended to have the Board regulate the size of [union] fines and establish standards with respect to their reasonableness." 59

In the subsequent Booster Lodge case, ${ }^{60}$ the Labor Board reaffirmed its Arrow Development position. On appeal, the Court of Appeals for the District of Columbia Circuit reversed this portion of the Labor Board's decision, and held instead that the NLRB is obligated to consider the reasonableness of the amount of a union disciplinary fine when that issue is appropriately raised in an unfair labor practice proceeding. ${ }^{61}$

However, the Supreme Court rejected the District of Columbia Court's analysis in favor of the Labor Board's position. ${ }^{62}$ The Court indicated that

[t]he underlying basis for the holdings of Allis-Chalmers and Scofield was not that reasonable fines were noncoer-

${ }^{55} 185$ N.L.R.B. 365 , enforcement denied sub nom. O'Reilly v. NLRB, 472 F.2d 426 (9th Cir. 1972). See text accompanying note 61 infra.

${ }^{56}$ This amount represented $\$ 500$ on the debt, $\$ 26.50$ in costs and $\$ 1.50$ for issuance of the writ of execution. 185 N.L.R.B. at 366 n.1.

${ }_{57}$ The strikebreaking member had earned a total of $\$ 610.62$ during the strike, with net earnings of $\$ 511.33$. Id. at 365 . Thus the amount of the state court judgment actually exceeded the worker's net earnings.

${ }^{58} \mathrm{Id}$. at 367 .

59 Id. at 368. The Board also noted:

Where Congress desires that the Board make this type of determination, it has said so. Thus, Sec. 8(b)(5) of the Act [29 U.S.C. $\$ 158(b)(5)(1970)]$ authorizes the Board to decide whether or not initiation fees charged of employees required to join a labor organization under a union-security clause are excessive and discriminatory.

Id. at 268 n.19.

${ }_{60}$ Booster Lodge 405, IAM, 185 N.L.R.B. 380 (1970).

${ }^{61}$ Booster Lodge 405, IAM v. NLRB, 459 F.2d 1143 (D.C. Cir. 1972). Accord, Morton Salt Co. v. NLRB, 472 F.2d 416 (9th Cir. 1972).

${ }^{62}$ NLRB v. Boeing Co., 412 U.S. 67 (1973). 
cive under the language of $\S 8(\mathrm{~b})(1)(\mathrm{A})$ of the Act, but was instead that those provisions [sic] were not intended by Congress to apply to the imposition by the union of fines not affecting the employer-employee relationship and not otherwise prohibited by the Act. ${ }^{63}$

It further noted that "[i]ssues as to the reasonableness or unreasonableness or [union] fines must be decided upon the basis of the law of contracts, voluntary associations, or such other principles of law as may be applied in a forum competent to adjudicate the issue." 64 Since it believed that state tribunals, rather than the NLRB, were best equipped to resolve these traditional legal questions, it concluded that the Labor Board was not obligated by section $8(\mathrm{~b})(1)(\mathrm{A})$ to consider the question of reasonableness in an unfair labor practice case.

These Labor Board and Supreme Court decisions constitute a clear departure from prior holdings pertaining to the union discipline area, and do not conform to the Congressional intent underlying the enactment of the Taft-Hartley amendments to the NLRA. Furthermore, they have myopically ignored the realities of industrial dynamics. Labor organizations have already imposed disciplinary fines of up to $\$ 14,000$ upon individual members, ${ }^{65}$ and it should be obvious to the most casual student of labor relations that the possibility of a judgment of such magnitude against any but the most extraordinary union worker would have a substantial chilling effect upon that person's exercise of his rights. ${ }^{66}$ In addition, it is not difficult to perceive the significant impact which such a threat would have upon other workers who might be contemplating the exercise of their rights. ${ }^{67}$ It is therefore imperative that the rationale of the Labor Board and Supreme Court decisions be carefully analyzed. ${ }^{68}$

${ }^{63}$ Id. at 72 .

${ }^{64} I d$. at 74.

${ }^{65}$ See Atleson, supra note 33, at 722; Christensen, supra note 33, at 276.

${ }^{66}$ The fact that the fines imposed might not be collectible in a subsequent state court action due to their unreasonable nature would not really detract from their coerciveness at the time of their imposition. See text accompanying note 111 infra; Local 167, Progressive Mine Workers v. NLRB, 422 F.2d 538, 542 (7th Cir.), cert. denied, 399 U.S. 905 (1970); NLRB v. American Bakery Workers, Local 300, 411 F.2d 1122, 1126 (7th Cir. 1969). Concerning the reluctance of many state courts to inquire into the reasonableness of fines in collection actions, see notes 147-51 infra \& accompanying text.

67 That such persons may technically avoid the possibility of enforceable disciplinary fines by resigning from the union before engaging in the contemplated activity, see notes 52-54 supra \& accompanying text, is not really a meaningful answer. Only an unusually well-informed union member would even be aware of his right in this regard. Furthermore, the member may not be able to afford the loss of the important monetary benefits (e.g., pension and health insurance rights) incidental to membership which would be incurred by resignation from the union.

${ }^{68}$ Although the mere imposition of an excessively large fine upon a member who has exercised some right protected by the NLRA might certainly have some adverse effect 


\section{Analysis of Labor Board and Supreme Court REASONING}

To evaluate the reasoning of the Labor Board and Supreme Court concerning the reasonableness issue, the rationales of the Allis-Chalmers, Scofield and Marine Workers decisions will be examined, and the legislative history of the pertinent NLRA provisions reviewed. Furthermore, the effect of the proviso to section 8(b)(1)(A) upon this question must be evaluated, along with a consideration of the implications which may reasonably be derived from other relevant NLRA sections.

\section{A. Relevance of "Reasonableness" Language in Allis-Chalmers and Scofield}

In the Allis-Chalmers decision, the Supreme Court expressly recognized the right of unions to utilize disciplinary fines enforceable in court in lieu of the more Draconian alternative of expulsion. The Court noted:

It is no answer that the proviso to $\S 8(\mathrm{~b})(1)(\mathrm{A})$ preserves to the union the power to expel the offending member. Where the union is strong and membership therefore valuable, to require expulsion of the member visits a far more severe penalty upon the member than a reasonable fine. ${ }^{69}$

The Court similarly indicated that "the proviso preserves the right of unions to impose fines, as a lesser penalty than expulsion "70 This reasoning implicitly recognized that for a disciplinary fine to be less coercive than expulsion, the amount exacted must be "reasonable," for it is intuitively obvious that the enforcement of an unreasonably large fine would visit a substantially greater burden upon an individual than would mere expulsion. ${ }^{71}$

The Allis-Chalmers opinion's preoccupation with "reason-

upon the disciplined individual, as well as upon others, such union action is protected by the language of the proviso to $\$ 8(\mathrm{~b})(1)(A)$ so long as actual or threatened expulsion is the only means being contemplated by the labor organization to enforce its fine. See note 4 sufra. For this reason, the discussion of this Article is concerned only with the situation where a union has imposed an unreasonably large fine which it either has sought or threatened to enforce through court action.

${ }^{69}$ NLRB v. Allis-Chalmers Mfg. Co., 388 U.S. 175, 183 (1967) (emphasis supplied).

${ }^{70} \mathrm{Id}$. at $191-92$.

71 The Allis-Chalmers Court did not resolve the reasonableness issue since it was not presented with the argument that the fines in question were unreasonably large. Id. at 192-93 n.30. Furthermore, it indicated that " $[t]$ here may be concern that court enforcement may permit the collection of unreasonably large fines. However, even were there evidence that Congress shared this concern, this would not justify reading the Act also to bar court enforcement of reasonable fines." Id. (footnote omitted). 
ableness" was shared by both concurring Justice White and dissenting Justice Black. In his concurring opinion, Justice White observed:

[S]ince expulsion would in many cases-certainly in this one involving a strong union-be a far more coercive technique for enforcing a union rule and for collecting a reasonable fine than the threat of court enforcement, there is no basis for thinking that Congress, having accepted expulsion as a permissible technique to enforce a rule in derogation of $\S 7$ rights, nevertheless intended to bar enforcement by another method [court action] which may be far less coercive. ${ }^{72}$

Justice Black's dissent echoed the same refrain when it summarized its interpretation of the majority holding: "[T]he Court's holding boils down to this: a court-enforced reasonable fine for nonparticipation in a strike does not 'restrain or coerce' an employee in the exercise of his right not to participate in the strike."73 The Supreme Court's emphasis upon reasonableness was continued in the Scofield decision, in which it noted that under Allis-Chalmers, "[a] union rule, duly adopted and not the arbitrary fiat of a union officer, forbidding the crossing of a picket line during a strike [is] . . . enforceable against voluntary union members by expulsion or a reasonable fine."74

The frequent mention of the reasonableness requirement in the Supreme Court's Allis-Chalmers and Scofield opinions was the primary consideration which induced the District of Columbia Circuit to reject the Labor Board's position in the Booster Lodge case. $^{75}$

In light of the [Supreme] Court's emphasis on the requirement of "reasonable fines" if a union is to avoid a violation of the Act . . . we must conclude that the imposition of an unreasonably large fine, at least where

${ }^{72}$ Id. at 198 (emphasis supplied).

${ }^{73} \mathrm{Id}$. at 200-01 (emphasis supplied). It is interesting to note that even the attorney who argued the Allis-Chalmers case before the Supreme Court on behalf of the union recognized the "reasonableness" limitation in the Court's opinion. In a subsequent article, he indicated that Allis-Chalmers only determined that "a union suit to collect a reasonable fine imposed on a member for violating a 'no strikebreaking' rule does not violate section $8(b)(1)$." Silard, supra note 33 , at 190 .

${ }_{74}$ Scofield v. NLRB, 394 U.S. 423, 428 (1969) (emphasis supplied). Elsewhere in its opinion, the Scofield Court reiterated its belief that the enforcement of a proper union rule "by reasonable fines does not constitute the restraint or coercion proscribed by $\S$ $8(\mathrm{~b})(1)(\mathrm{A}) . "$ Id. at 436.

Although the Supreme Court had not discussed the "reasonableness" requirement in its 1968 decision in Marine Workers, this omission was easily explained by the fact that Marine Workers involved only expulsion. Therefore, considerations relevant to fine situations were not pertinent.

${ }_{75}$ Booster Lodge 405, IAM v. NLRB, 459 F.2d 1143, $1156-57$ (D.C. Cir. 1972). 
the union threatens or actually attempts court enforcement of the fine, may be coercive and restraining within the meaning of section $8(\mathrm{~b})(\mathrm{l})(\mathrm{A}){ }^{76}$

This same interpretation of the Allis-Chalmers and Scofield decisions was adopted by the Ninth Circuit in its Morton Salt opinion. ${ }^{77}$ Nevertheless, in Boeing, the Supreme Court curiously rejected the clear implications of its prior decisions.

The Boeing Court recognized the logic underlying the contention that the Allis-Chalmers and Scofield opinions had implicitly indicated that the imposition of an unreasonably large union fine would constitute an unfair labor practice. ${ }^{78}$ However, it reasoned that " $[t]$ his interpretation . . . permissible as it may be, is only dicta, since in both Allis-Chalmers and in Scofield the reasonableness of the fines was assumed."79 It then proceeded to reject the earlier precedents' implications. The Court interpreted AllisChalmers and Scofield as placing "fines not affecting the employer-employee relationship" outside the scope of section $8(\mathrm{~b})(\mathrm{l})(\mathrm{A})$ because "Congress had not intended by enacting this section to regulate the internal affairs of unions to the extent that would be required in order to base unfair labor practice charges on the levying of such fines." 80

Although the Labor Board had disingenuously attempted in its Arrow Development decision to reconcile its position on the reasonableness issue with the recurrent reference in the AllisChalmers and Scofield opinions to reasonable fines, ${ }^{81}$ the Supreme

${ }^{76} \mathrm{Id}$. at $1156-57$. Since it is the statutory obligation of the NLRB to resolve all of the issues relevant to an unfair labor practice proceeding before it, the D.C. Circuit concluded that the Labor Board must consider the reasonableness question where it is appropriately raised. Id. at 1157. See NLRA $\S \S 10$ (a)-(c), 29 U.S.C. $\$ \S 160(a)$-(c) (1970) (NLRB's unfair labor practice responsibility).

7 Morton Salt Co. v. NLRB, 472 F.2d 416, 422-23 (9th Cir. 1972). See O'Reilly v. NLRB, 472 F.2d 426 (9th Cir. 1972).

${ }^{78}$ NLRB v. Boeing Co., 412 U.S. 67, 72 (1973).

${ }^{79}$ Id.

so Id. at 73 .

${ }^{81}$ Machinists Lodge No. 504, 185 N.L.R.B. 365, 368 (1970):

Thus the Court's findings that the fines in those cases [Allis-Chalmers and Scofield] were reasonable seems directed to enforcing courts, encouraging those courts to make an independent determination of the reasonableness of the fine in each case presented in the same fashion as courts limit other union discipline which imposes a severe hardship. Such considerations are of an equitable nature rather than of the character of restraint and coercion with which the National Labor Relations Acts treats.

The only possible support for this anomalous interpretation of the Allis-Chalmers and Scofield decisions' frequent emphasis upon reasonable fines is derived from an oblique reference in a footnote in Allis-Chalmers "that the state courts, in reviewing the imposition of union discipline, find ways to strike down 'discipline [which] involves a severe hardship.' " 388 U.S. at 193 n.32. While this analysis may not be wholly absurd, see Note, supra note 33, at 1097, such a passing reference in a footnote should not be so seized upon to negate the frequent textual references in both the Allis-Chalmers and Scofield decisions to the necessity of having reasonable fines. Apparently the Supreme Court 
Court refused to utilize such a questionable formula. ${ }^{82}$ It rejected the implications contained in the Allis-Chalmers and Scofield dicta in favor of policy considerations which it believed supported a contrary result. Since the conclusion reached by the Boeing Court constitutes a significant departure from the precedents established in the Allis-Chalmers and Scofield decisions, an evaluation of these policy considerations is in order.

\section{B. Implications of the Legislative History}

In supporting its conclusion that section $8(\mathrm{~b})(1)(\mathrm{A})$ was not intended by Congress to obligate the Labor Board to evaluate the reasonableness of union fines in unfair labor practice proceedings, the Boeing Court reiterated much of the analysis of legislative history which had been utilized in Allis-Chalmers. ${ }^{83}$ From this evaluation, the Court determined that "Congress had not intended by enacting this section to regulate the internal affairs of unions to the extent that would be required in order to base unfair labor practice charges on the levying of such [unreasonable] fines." 84 However, the Court's reliance upon the legislative history of the Taft-Hartley amendments to the NLRA to support its "reasonableness" determination proves too much.

Even a cursory examination of the literal language contained in section $8(\mathrm{~b})(\mathrm{l})(\mathrm{A})^{85}$ discloses an explicit contradiction between the main portion of that section and its proviso. ${ }^{86}$ This

agreed. See note 82 infra. However, in Note, Determining the Reasonableness of Fines Imposed On Union Members: The Role of NLRB, 1973 DUKE L.J. 328, $331 \mathrm{n} .22$ [hereinafter cited as Reasonableness of Fines], the author attempts to support the Labor Board's position by suggesting that the reasonableness references in Allis-Chalmers and Scofield "could refer to the procedures for imposing the fines and the purposes for which the fines are imposed, as opposed to the amount of the fine."

${ }_{82}$ The Boeing Court expressly noted the unique rationalization of the Labor Board. 412 U.S. at $76 \mathrm{n} .11$. The conspicuous absence of any indication of support for the NLRB's theory negates any inference that the Boeing Court concurred in the Labor Board's analysis.

${ }_{83} 412$ U.S. at 73-74. See note 30 supra \& accompanying text.

84412 U.S. at 73. The Boeing Court thus eschewed a literal interpretation of $\S 8(b)(1)(A)$ in favor of a statutory construction founded upon policy considerations, just as it had previously done in Allis-Chalmers, Marine Workers and Scofield.

Not surprisingly, when presented with a choice between literalism in statutory construction and public policy implementation, the Supreme Court chose the latter course. In all three opinions [Allis-Chalmers, Marine Workers \& Scofield] the Court recognized that the decisional key is more appropriately found in the underlying legislative purpose than in a literal construction of the legislative text, which may have been directed toward a different area of congressional concern.

Silard, supra note 33 , at 193 (1969).

${ }_{85}$ For the text of $\$ 8(\mathrm{~b})(1)(\mathrm{A})$, see note 4 supra.

${ }^{86}$ See Kovarsky, Union Discipline, 19 LAB. L.J. 667, 669, 671 (1968). "Conflict is inevitable because a member cannot be restrained or coerced; yet, restraint or coercion is inevitable if a union is legislatively authorized to prescribe rules and regulations to govern its members." Id. 669 . 
conflict was recognized by Senator Hatch during the debates surrounding the proposed Taft-Hartley Act.

It appears to me that by prohibiting unions from interfering with the employees' exercise of their rights relating to the selection of representatives, and in the next sentence stating that such a prohibition shall not impair the right of a union to prescribe its own rules with respect to the acquisition or retention of membership, we are outlining the boundaries of a legalistic battlefield which may lead to unlimited argument. ${ }^{87}$

While it is certainly appropriate to examine the legislative history pertaining to the Taft-Hartley amendments in an effort to resolve the obvious interpretive dilemma, ${ }^{88}$ it must be concluded that the Supreme Court's evaluation of the congressional debates, as they pertain to the reasonableness issue, is not supported by anything in the legislative history. Since the Boeing Court's legislative analysis was almost exclusively premised upon the earlier Allis-Chalmers consideration of the congressional debates concerning the Taft-Hartley amendments, we are remanded to an examination of the Allis-Chalmers decision in this regard. ${ }^{89}$

The Allis-Chalmers Court recognized the dearth of legislative debates concerning the propriety of union disciplinary activity, but it nevertheless concluded:

[w] hat legislative materials there are dealing with $\S 8(b)(1)(\AA)$ contain not a single word referring to the application of its prohibitions to traditional internal union discipline in general, or disciplinary fines in particular. On the contrary there are a number of assurances by its sponsors that the section was not meant to regulate the internal affairs of unions. ${ }^{90}$

872 NLRB, Legislative History of the Labor Managemeno Relations Act, 1947 at 1479 (1948). Concerning Professor Cox' prediction of heavy litigation before the ambiguities of $\S 8(\mathrm{~b})(1)(\mathrm{A})$ could be resolved, see note 6 supra \& accompanying text.

NLRB v. Allis-Chalmers Mfg. Co., 388 U.S. 175, $179-80$ (1967); National Woodwork Mfrs. As'n v. NLRB, 386 U.S. 612, 619-20 (1967); NLRB v. Teamsters Local 639, 362 U.S. 274, 292 (1960). See also text accompanying notes 28-29 supra.

${ }^{89}$ It should be noted at least parenthetically that the Boeing Court's heavy reliance upon the legislative analysis contained in the Allis-Chalmers opinion may have been wholly inappropriate, due to the fact that the Allis-Chalmers decision only interpreted the congressional debates to permit "reasonable fines." See notes 69-74 supra \& accompanying text. Under these circumstances, since the Boeing Court expressly rejected the implications contained in the Allis-Chalmers dicta concerning reasonableness of fines, see notes 78-80 supra \& accompanying text, it is somewhat incongruous to find that the primary support for the Boeing conclusion is derived from the Allis-Chalmers decision. Nonetheless, it is still informative to consider the legislative history in an effort to resolve the ambiguity which is inherent in $\$ 8(\mathrm{~b})(1)(\mathrm{A})$.

${ }_{90} 388$ U.S. at 185-86. 
This sweeping conclusion is defective for at least two major reasons. ${ }^{91}$ First, much of the legislative material which it relied upon to support its theory that Congress did not intend to regulate the internal affairs of unions was derived from the debates surrounding section $8(\mathrm{~b})(2) .{ }^{92}$ This section was clearly aimed solely at protecting workers from union restraints upon their external employment rights. It is apparent from the unambiguous language of this provision that it was not intended to affect matters of wholly internal union concern, for it only proscribes union activity aimed at causing an employer-i.e., an external party-to discriminate against an employee with respect to his terms and conditions of employment. Second, despite the fact that some of the legislative comments pertaining to section $8(\mathrm{~b})(1)(\mathrm{A})$ indicated a general congressional intent to avoid interference with the internal affairs of labor organizations, ${ }^{93}$ there is no real evidence that Congress intended to provide unions with carte blanche over the area of member discipline. ${ }^{94}$ This is particularly true with respect to fines which the disciplining union contemplates enforcing in court collection suits. "T5 "The admitted fact that Congress did not wish to regulate the internal operation of a union does not, of itself, sustain a conclusion that any act resulting from some phase of those internal operations if [sic] left free from any restriction."96 Furthermore, the mere presence in the legislative history of several oblique references to the desire of some Congressmen to avoid interference with internal union affairs should not be unhesitatingly seized upon as an indication of general congressional intent to permit labor organizations to enforce excessively large disciplinary fines. ${ }^{\mathbf{9 7}}$

${ }^{91}$ It should also be pointed out that an interesting anomaly which was never satisfactorily explained by the Allis-Chalmers Court concerns its implicit assumption that court enforcement of union disciplinary fines involves only "internal union affairs," despite the invocation of the assistance of the clearly external judicial machinery. $C f$. Shelley v. Kraemer, 334 U.S. 1 (1948). See Christensen, supra note 33, at 271.

92388 U.S. at $184-85,190$. See Christensen, supra note 33 , at 271 . Concerning the applicability of $\S 8(\mathrm{~b})(2), 29$ U.S.C. $\S 158(\mathrm{~b})(2)$ (1970), see note 23 supra. For text of $\S$ $8(\mathrm{~b})(2)$, see note 114 infra.

${ }_{93}$ See 388 U.S. at 185-89. See also note 30 supra.

${ }^{94}$ This fact was clearly recognized by the Supreme Court itself in Marine Workers, where the Court found a $\S 8(\mathrm{~b})(1)(\mathrm{A})$ violation when a labor organization expelled a member for failing to exhaust all available internal union procedures before filing an unfair labor practice charge with the Labor Board. Not even the express language of the proviso permitted such union activity. See also notes 38-54 supra \& accompanying text.

95 "II]t is one thing to state that the 1947 amendments left the union free to levy fines, but it is quite a different matter to state that enforcement of those fines by nonunion tribunals was thereby also left free from restriction." Christensen, supra note 33 , at 271.

${ }_{96}$ Id. See also Atleson, supra note 33, at 698 .

${ }_{97}$ The difficulty of ascertaining the specific legislative intent pertaining to a particular provision from the passing comments of a few Congressmen should be readily apparent. Such interpretive statements may well not reflect the attitudes of the overall legislative body. 
Since an examination of the relevant legislative history ${ }^{98}$ does not really provide any meaningful indication of the true congressional intent concerning the applicability of section $8(\mathrm{~b})(\mathrm{l})(\mathrm{A})$ to unreasonably large disciplinary fines which a union contemplates enforcing through court action, ${ }^{99}$, it would be beneficial to examine the general policies underlying the enactment of the Taft-Hartley Act amendments. In this manner, it may be possible to discern the interpretation which Congress most likely intended.

\section{Concern for Individual Rights Protected by the NLRA}

"One of the major aims of the Wagner Act of 1935 was to protect industrial rights of individual employees." ${ }^{100}$ However, much of the protection afforded workers was provided through the vehicle of organizational strength-to the derogation of individual freedom in some cases. ${ }^{101}$ To insure that individual rights could not become totally subjugated to organizational objectives, the 1947 Congress included a clause in the TaftHartley amendment to section 7 of the NLRA which expressly recognized the right of individual employees to refrain from any and all of the concerted activities protected by that provision. ${ }^{102}$ "To protect the right to refrain from concerted activity, Congress enacted Section $8(\mathrm{~b})(1)(\mathrm{A}) \ldots . .{ }^{103}$ Since it is well estab-

${ }^{98}$ Although the Allis-Chalmers Court also placed some reliance upon the enactment of the Landrum-Griffin Act as an indication of Congressional belief in 1959 that the prior Taft-Hartley amendments had not imposed any restrictions upon the internal affairs of labor organizations, 388 U.S. at 193-95, one commentator has noted:

Any suggestion that section 101(a)(5) of the 1959 act bars all applications of section 8(b)(1)(A) ... is dispelled by section 103 of the 1959 act: "Nothing contained in this title shall limit the rights and remedies of any member of a labor organization under any State or Federal law ...." Thus on closer inspection the proscription of court-enforceable union fines under section $8(\mathrm{~b})(1)(\mathrm{A})$ is not incompatible with the 1959 legislation.

Note, supra note 33, at 65. See also Atleson, supra note 33, at 725; Christensen, supra note 33 , at 272.

${ }_{99}$ It is not difficult to understand the lack of legislative debate concerning the propriety of court-enforced union fines. "Since court enforcement of union fines is rare, one would expect that a search through the legislative history would be unrewarding." Atleson, supra note 33, at 701. For further criticism of the questionable evaluation of legislative history by the Allis-Chalmers Court, see id. 701, 706-11; Christensen, supra note 33 , at $268-74$.

100 Atleson, supra note 33 , at 682 .

${ }^{101}$ See, e.g., Mastro Plastics Corp. v. NLRB, 350 U.S. 270, 280 (1956) (union waiver of right of employees to strike); NLRB v. Rockaway News Supply Co., 345 U.S. 71 (1953) (union waiver of right of employees to refuse to cross lawful picket line); Medo Photo Supply Corp. v. NLRB, 321 U.S. 678 (1944) (loss of right to contract with employer individually where bargaining representative has been selected); J.I. Case Co. v. NLRB, 321 U.S. 332 (1944) (same).

102 See note 5 supra. "Thus, the pre-1947 bias in favor of concerted activity has been modified in that individual employees have countervailing rights protected by the statute." Atleson, supra note 33, at 685. See also NLRA \& 9(a), 29 U.S.C. \& 159(a) (1970) (recognizing the right of workers to preseno grievances in their individual capacity in some cases).

${ }^{103}$ Atleson, supra note 33 , at 684 . 
lished that an employee does not automatically waive his section 7 rights and the protection of section $8(\mathrm{~b})(1)(\mathrm{A})$ when he joins a labor organization, ${ }^{104}$ it is apparent that the right of a union to impose disciplinary measures upon a member, which was recognized in Allis-Chalmers and Scofield, must be balanced against the correlative freedom of the individual to abstain from organizational activity.

Even the Scofield Court recognized that "if the [union disc1plinary] rule invades or frustrates an overriding policy of the labor laws the rule may not be enforced, even by fine or expulsion, without violating $\S 8(\mathrm{~b})(1) . "{ }^{105}$ Although the Allis-Chalmers and Scofield decisions have provided a labor organization with an appropriately expansive authority to impose discipline where necessary to preserve its viability as the employee's selected bargaining representative, ${ }^{106}$ the specific emphasis of those opinions upon the reasonable character of permissible disciplinary fines ${ }^{107}$ should not be casually disregarded at the expense of individual rights.

The imposition of a reasonable fine upon a member who has engaged in some activity in violation of a legitimate union rule protects the labor organization as an institution, while only derogating from individual freedom to the extent necessary to further the congressional objective of enhancing the efficacy of the chosen bargaining representative. However, where an, excessive fine is levied, and judicial enforcement is threatened or actually commenced, the union's behavior is no longer merely protective, but becomes retributive. While such punitive action may certainly have the very undesirable effect of wholly deterring the future exercise of secoion 7 rights by the disciplined individual, "[f]ar greater is the repressive effect it may have on all other members of the union who witness its use." ${ }^{108}$ Such an unreasonable disciplinary measure could thus preclude the exer-

${ }^{104}$ See, e.g., NLRB v. Industrial Union of Marine Workers, 391 U.S. 418 (1968). See also International Molders, Local 125, 178 N.L.R.B. 208 (1969), enforced, 442 F.2d 92 (7th Gir. 1971); Local 138, IUUOE, 148 N.L.R.B. 679 (1964).

${ }^{105}$ Scofield v. NLRB, 394 U.S. 423, 429 (1969).

[Section] 8(b)(1) leaves a union free to enforce a properly adopted rule which reflects a legitimate union inoerest, impairs no policy Congress has imbedded in the labor laws, and is reasonably enforced against union members who are free to leave the union and escape the rule.

Id. at 430 .

${ }_{108}$ Such union autonomy is certainly proper to further the legislative objectives underlying the NLRA, since "[o]verzealous judicial interference could weaken a union in its capacity of bargaining representative, a role for which it has been delegated Congressional power." Atleson, supra note 33 , at 686 .

${ }^{107} \mathrm{See}$ nooes $69-77$ supra \& accompanying text.

108 Summers, supra note 16 , at 1050. 
cise of protected rights by union members for a substantial period of time. Not only would this result be unnecessary to protect the legitimate authority of the labor organization, but it would negate the important congressional emphasis upon individual freedom evidenced by the Taft-Hartley amendment to section 7 of the NLRA. ${ }^{109}$

The Boeing Court's belief that state courts may review the reasonableness of disciplinary fines in collection actions ${ }^{110}$ does not detract from the extreme coerciveness of an unreasonably large fine at the time of its imposition.

The levy of a fine is calculated to force an individual both to pay money and to engage in particular conduct against his will. This is true regardless of the ultimate collectability of the fine. A man who is held up at gunpoint is coerced whether or not the gun is loaded. As with the levy of a fine, the coercion lies in the calculated threat and .... the "argument that the fines imposed were not collectable in a court of law, even if accepted is beside the point.' The imposition of a fine has immediate coercive consequences. Faced with the possibility of action against him, the employee may well be, for practical purposes, impelled to forego his statutory right $[\mathrm{s}]$... rather than risk involvement in a lawsuit whose outcome he cannot predict. Or, should he choose to take that risk, he will find it necessary to hire counsel whose services he ordinarily would not require. ${ }^{111}$

It is apparent that if the protection expressly afforded to individual employees in section $8(\mathrm{~b})(1)(\mathrm{A})$ and the Taft-Hartley amendment to section 7 is to be meaningfully effectuated, the Labor Board will have to examine the coerciveness of excessive disciplinary fines in unfair labor practice proceedings. ${ }^{112}$

This pragmatic approach to the problem of internal union discipline [would do] much to reconcile the rights of union members with the need for effective union authority. It [would allow] unions to effectively enforce

${ }^{109}$ See note 102 supra \& accompanying text.

110 NLRB v. Boeing Co., 412 U.S. 67, 76-77 (1973).

111 Booster Lodge No. 405, IAM, 185 N.L.R.B. 380, 381 (1970).

112 "The broad theory in Marine $\mathcal{F}^{3}$ Shipbuilding [and Scofield] that no lawful discipline may frustrate a policy imbedded in the labor laws seems to support a determination that the Board will have to consider whether union fines are reasonable." Johannesen, Disciplinary Fines as Interference With Protected Rights: Section $8(b)(1)(A), 24$ LAB. L.J. 268, 280 (1973). 
their legitimate rules without destroying their members' rights to refrain from participating in union activities. ${ }^{113}$

Furthermore, other policies emanating from the NLRA indicate the need for such an approach.

\section{Other Policy Considerations Evidenced in the NLRA}

1. Sections $8(a)(3)$ and $8(b)(2)$

Section $8(b)(2)$ of the NLRA $^{114}$ prohibits a union from interfering with the employment relationship which exists between an individual worker and his employer. Both the AllisChalmers and Scofield decisions specifically recognized that this provision proscribes "enforcement of a union's internal regulations to affect a member's employment status." 115 Although it is obvious that this section prevents a labor organization from attempting to enforce disciplinary action by inducing, or attempting to induce, the termination or suspension of the

${ }^{113}$ Recent Decisions, 6 GA. L. REv. 631, 643 (1972).

${ }^{114}$ Section 8(b)(2) of the NLRA, 29 U.S.C. \$ 158(b)(2) (1970), provides: agents-

(b) It shall be an unfair labor practice for a labor organization or its

$\cdots \cdots$

(2) to cause or attempt to cause an employer to discriminate against an employee in violation of subsection (a)(3) of this section or to discriminate against an employee with respect to whom membership in such organization has been denied or terminated on some ground other than his failure to tender the periodic dues and the initiation fees uniformly required as a condition of acquiring or retaining membership : ...

Section 8(a)(3), 29 U.S.C. $\S 158(a)(3)$ (1970), makes it an unfair labor practice for an employer

by discrimination in regard to hire or tenure of employment or any term or condition of employment to encourage or discourage membership in any labor organization: Provided, That nothing in this subchapter, or in any other statute of the United States, shall preclude an employer from making an agreement with a labor organization (not established, maintained, or assisted by any action defined in this subsection as an unfair labor practice) to require as a condition of employment membership therein on or after the thirtieth day following the beginning of such employment or the effective date of such agreement, whichever is the later, (i) if such labor organization is the representative of the employees as provided in section 159(a) of this title, in the appropriate collective-bargaining unit covered by such agreement when made, and (ii) unless following an election held as provided in section 159(e) of this title within one year preceding the effecoive date of such agreement, the Board shall have certified that at least a majority of the employees eligible to vote in such election have voted to rescind the authority of such labor organization to make such an agreement: Provided further, That no employer shall justify any discrimination against an employee for nonmembership in a labor organization (A) if he has reasonable grounds for believing that such membership was not available to the employee on the same terms and conditions generally applicable to other members, or (B) if he has reasonable grounds for believing that membership was denied or terminated for reasons other than the failure of the employee to tender the periodic dues and the initiation fees uniformly required as a condition of acquiring or retaining membership ....

115 See Scofield v. NLRB, 394 U.S. 423, 428 (1969); NLRB v. Allis-Chalmers Mfg. Co., 388 U.S. 175, 184 (1967). 
member in question by his employer, ${ }^{116}$ its implications should have further application to the area of union discipline.

When a labor organization imposes a disciplinary fine which is so excessively large that it substantially surpasses the level necessary to deter violations of legitimate union rules, the effect of this action-to the extent a reasonable limit is exceeded-is quite analogous to an employment suspension. ${ }^{117}$ Although this situation technically would not come within the purview of section $8(b)(2)$, since the union would not be attempting to cause the employer himself to affect the member's employment status, such unreasonable activity would be violative of the important policy considerations underlying that provision. Irresponsible union disciplinary action should not be accepted by the mere exaltation of form over substance, for "[w]hile unions have the right to enforce their internal rules, they cannot do so by imposing what amounts to the financial equivalent of job loss."118 Since it is clear that " $[t]$ he NLRB and the courts will intervene if the discipline affects the employer-employee relationship,"119 it would be inappropriate for the Labor Board and the courts to abdicate this responsibility in the union discipline area merely because the labor organization's actions do not satisfy the express language of section $8(b)(2)$. Otherwise, the vital policy considerations evidenced by that provision will not be fully effectuated.

\section{The Duty of Fair Representation}

In upholding the disciplinary fines involved in the Scofield case, the Supreme Court expressly indicated that there was "no dereliction by the union of its duty of fair representation." 120 The apparent implication of this determination is that invidious union disciplinary action would be considered contrary to the established fair representation doctrine.

Although Allis-Chalmers specifically indicated that no fair representation issue was presented in that case, ${ }^{121}$ it is informative to note that it nonetheless discussed the general rationale of that doctrine.

It was because the national labor policy vested

\footnotetext{
${ }^{116}$ Electric Auto-Lite Co., 92 N.L.R.B. 1073 (1950), enforced per curiam, 196 F.2d 500 (6th Cir.), cert. denied, 344 U.S. 823 (1952). See also Radio Officers' Union v. NLRB, 347 U.S. 17 (1954).

117 See Gould, supra note 33, at 1090.

118 Recent Decisions, supra note 113, at 642. See Silard, supra note 33, at 191.

119 Harrison, Union Discipline and the Employer-Employee Relationship, 22 LAB. L.J. 216 , 217 (1971).

120394 U.S. at 436.

121388 U.S. at 195.
} 
unions with power to order the relations of employees with their employer that this Court found it necessary to fashion the duty of fair representation. That duty "has stood as a bulwark to prevent arbitrary union conduct against individuals stripped of traditional forms of redress by the provisions of federal labor law.'122

The important policy considerations underlying the duty of fair representation should have particular significance with respect to the propriety of union disciplinary action. This is due to the fact that probably no area of labor organization activity affects the union-member relationship more directly than the imposition of union discipline.

Under the fair representation doctrine, "the exclusive agent's statutory authority to represent all members of a designated unit includes a statutory obligation to serve the interests of all members without hostility or discrimination toward any, to exercise its discretion with complete good faith and honesty, and to avoid arbitrary conduct." ${ }^{123}$ Although "[a] breach of the statutory duty of fair representation occurs only when a union's conduct toward a member of the collective bargaining unit is arbitrary, discriminatory, or in bad faith,"124 an unreasonably large disciplinary fine arguably violates this doctrine. ${ }^{125}$

A fine which is not reasonably related to the disciplining labor organization's right to protect its vitality as the recognized bargaining representative should be regarded as retaliatory and arbitrary, in the same manner any fine imposed upon a member who has filed a decertification petition is so regarded. ${ }^{126}$ An excessively large fine is retributive, rather than defensive. As such, it should be viewed as an arbitrary and invidious form of union pressure aimed at deterring the exercise of protected rights by its members. Such a clear derogation of union responsibility vis-à-vis its members should therefore be found to constitute the type of activity which "frustrates an overriding policy of the labor laws"127 - the duty of fair representation. This type of unreasonable discipline should therefore be determined to violate section $8(\mathrm{~b})(\mathrm{l})(\mathrm{A}) .^{128}$

122 Id. at 181, quoting Vaca v. Sipes, 386 U.S. 171, 182 (1967).

123 Vaca v. Sipes, 386 U.S. 171,177 (1967).

${ }^{124} \mathrm{Id}$. at 190.

123 See Note, supra note 33, at 1097.

${ }^{126}$ See notes $43-51$ supra \& accompanying text.

${ }^{127}$ Cf. Scofield v. NLRB, 394 U.S. 423, 429 (1969).

${ }_{128}$ The Labor Board has clearly recognized that arbitrary and invidious union conduct is violative of $\S 8(\mathrm{~b})(1)(\mathrm{A})$. See, e.g., Rubber Workers, Local 12 v. NLRB, 368 F.2d 12, 15 (5th Cir. 1966), cert. denied, 389 U.S. 837 (1967); Miranda Fuel Co., Inc., 140 N.L.R.B. 181, 190 (1962), enforcement denied, 326 F.2d 172 (2d Cir. 1963). 
3. The Impropriety of "Reverse Preemption"

In its Boeing decision, the Supreme Court placed great emphasis upon its belief that state courts would evaluate the reasonableness of disciplinary fines in collection suits. ${ }^{129}$ It noted that "[s]ince state courts will have jurisdiction to determine reasonableness in the enforcement context in any event, the Board's independent determination of reasonableness in an unfair labor practice context might well yield a conflict when the two forums are called upon to review the same fine." ${ }^{130}$ To obviate such a problem, the Court concluded that the question of reasonableness should not be cognizable before the NLRB. Such reasoning not only is contrary to the express jurisdictional authority of the Labor Board, but constitutes a substantial departure from prior Supreme Court decisions pertaining to federal preemption in the area of labor relations.

Section 10(a) of the NLRA ${ }^{131}$ specifically provides:

The Board is empowered ... to prevent any person from engaging in any unfair labor practice (listed in section 158 of this title) affecting commerce. This power shall not be affected by any other means of adjustment or prevention that has been or may be established by agreement, law, or otherwise ....

Although this language was originally enacted as part of the Wagner Act in 1935, Congress in 1947 expressly indicated why the Taft-Hartley Act did not alter this provision.

By retaining the language which provides the Board's powers under section 10 shall not be affected by other means of adjustment, the conference agreement makes clear that, when two remedies exist, one before the Board and one before the courts, the remedy before the Board shall be in addition to, and not in lieu of, other remedies. ${ }^{132}$

In $N L R B$ v. Strong, ${ }^{133}$ the Supreme Court itself noted that "the business of the Board, among other things, is to adjudicate and remedy unfair labor practices," 134 and it recognized that the express language of section 10(a) indicates a clear congressional intention that the Labor Board's jurisdiction is not to be di-

${ }^{129}$ NLRB v. Boeing Co., 412 U.S. 67, 76 (1973).

${ }^{130} \mathrm{Id}$. at 77-78.

13129 U.S.C. § 160(a) (1970).

132 H.R. Conf. ReP. No. 510, 80th Cong., 1st Sess. 52 (1947).

133393 U.S. 357 (1969).

${ }^{134} \mathrm{Id}$. at 360 . 
minished by the fact that it is called upon to resolve contract questions which could be adjudicated before other forums. ${ }^{135}$

In light of the clear legislative intent expressed in section 10(a), which prior Supreme Court decisions specifically recognized, the Boeing conclusion is most curious. The Court's complete failure to explicate the reasons for its departure from recognized precedents makes it impossible to discern any rational basis for its action, apart from the obvious fact that the Court desired to achieve a particular result. Furthermore, the Court's reasoning is diametrically opposed to the principles underlying the well-established federal preemption doctrine.

The course of events that eventuated in the enactment of a comprehensive national labor law, entrusted for its administration and development to a centralized, expert agency, as well as the very fact of that enactment itself, reveals that a primary factor in this development was the perceived incapacity of common-law courts and state legislatures, acting alone, to provide an informed and coherent basis for stabilizing labor relations conflict and for equitably and delicately structuring the balance of power among competing forces so as to further the common good. ${ }^{136}$

To effectuate these vital considerations, the Supreme Court has enunciated the so-called Garmon doctrine:

When it is clear or may fairly be assumed that the activities which a State purports to regulate are protected by $\S 7$ of the National Labor Relations Act, or constitute an unfair labor practice under $\S 8$, due regard for the federal enactment requires that state jurisdiction must yield .... When an activity is arguably subject to $\S 7$ or $\S 8$ of the Act, the States as well as the federal courts must defer to the exclusive competence of the National Labor Relations Board ......137

Since the Garmon doctrine was unequivocally reaffirmed in

${ }^{135} I d$.

${ }^{136}$ Motor Coach Employees v. Lockridge, 403 U.S. 274, 286 (1971). See Teamsters Union v. Morton, 377 U.S. 252 (1964); Garner v. Teamsters Union, 346 U.S. 485, 490-91 (1953).

${ }^{137}$ San Diego Bldg. Trades Council v. Garmon, 359 U.S. 236, 244-45 (1959). See generally Cox, Federalism in the Law of Labor Relations, 67 HARv. L. REv. 1297 (1954); Hays, Federalism and Labor Relations in the United States, 102 U. PA. L. Rev. 959 (1954); Meltzer, The Supreme Court, Congress, and State Jurisdiction Over Labor Relations, 59 ColuM. L. REv. 6, 269 (1959); Michelman, State Power to Govern Concerted Employee Activities, 74 HaRv. L. Rev. 641 (1961); Updegraff, Preemption, Predictability and Progress in Labor Law, 17 HASTINGs L.J. 473 (1966); Wellington, Labor and the Federal System, 26 U. CHI. L. REv. 542 (1959). 
the Supreme Court's 1971 Lockridge decision, ${ }^{138}$ it is extremely difficult to justify the Boeing Court's reasoning that Labor Board jurisdiction must yield to state tribunals with respect to the reasonableness issue. ${ }^{139}$ Although the Court has recognized that state forums need not surrender jurisdiction

where the activity regulated [is] a merely peripheral concern of the Labor Management Relations Act . . . [o]r where the regulated conduct touche[s] interests so deeply rooted in local feeling and responsibility that, in the absence of compelling Congressional direction, we could not infer that Congress had deprived the states of the power to act, ${ }^{140}$

neither of these preemption corollaries can satisfactorily explain the Boeing Court's decision to divest the Labor Board of jurisdiction over the reasonableness area.

The imposition of unreasonably large disciplinary fines has the impermissible effect of deterring the exercise of protected section 7 rights by members. ${ }^{141}$ Such action further offends the important legislative policies which precipitated the enactment of sections $8(b)(2)$ and $8(a)(3)$ of the NLRA ${ }^{142}$ and which underlie the duty of fair representation. ${ }^{143}$ Under these circumstances it is clear that the propriety of excessively large union fines is not "a merely peripheral concern of the Labor Management Relations Act."

Although the traditional concern of state courts with the reasonableness issue in collection actions may well indicate the appropriateness of concurrent jurisdiction over this area, ${ }^{144}$ this would certainly not derogate from the statutory authority of the NLRB. ${ }^{145}$ Even where state tribunals are permitted to adjudicate

138 Motor Coach Employees v. Lockridge, 403 U.S. 274 (1971). See Cox, Labor Law Preemption Revisited, 85 HARV. L. Rev. 1337 (1972); Lesnick, Preemption Reconsidered: The Apparent Reaffirmation of Garmon, 72 Colum. L. REv. 469 (1972). Cf. St. Antoine, Judicial Caution and the Supreme Court's Labor Decisions, October Term 1971, 6 U. MICH. J.L. ReFORM 269, 286-87 (1973).

${ }^{139}$ It is interesting to note that even if the Boeing Court's belief that Congress did not intend in 1947 to regulate the internal affairs of labor organizations were correct, this would certainly not automatically provide state tribunals with the authority to consider the reasonableness of union disciplinary fines. The Court should have considered the possibility that Congress did not desire to permit any regulation of this area of union concern. $C f$. Teamsters Union v. Morton, 377 U.S. 252 (1964). "[T] filling a gap when it outlaws what federal law fails to outlaw; it is denying one party to an economic contest a weapon that Congress [may have] meant him to have available." Lesnick, supra note 138, at 478 . See Cox, supra note 138 , at 1365.

${ }^{140}$ San Diego BIdg. Trades Council v. Garmon, 359 U.S. 236, 243-44 (1959).

141 See notes 100-13 supra \& accompanying text.

${ }_{142}$ See notes 114-19 supra \& accompanying text.

143 See notes 120-28 supra \& accompanying text.

${ }^{144}$ See notes 179-87 infra \& accompanying text.

${ }^{145}$ See notes 131-35 supra \& accompanying text. 
issues which may be relevant to unfair labor practice proceedings before the Labor Board, it is well recognized that this in no way detracts from the plenary jurisdiction of the federal agency. ${ }^{146}$

\section{Difficulties with the Boeing Holding}

Under the doctrine enunciated in Boeing members of labor organizations upon whom disciplinary fines are imposed may anticipate many difficulties which were either ignored or misconceived by the Supreme Court. A brief consideration of the more apparent problems which have been created may hopefully provide the impetus for reconsideration of this jurisdictional question by the Labor Board or possibly by the Supreme Court.

\section{A. Adequacy of State Court Review of the Reasonableness of the Amount of a Fine}

One of the important considerations which induced the Boeing Court to conclude that there was no necessity for NLRB jurisdiction over the question of reasonableness was its belief that state courts adequately protect the rights of disciplined employees by reviewing the size of union fines in collection actions. ${ }^{147}$ It emphasized its notion that "state courts applying state law are quite willing to determine whether disciplinary fines are reasonable in amount."148 However, the Supreme Court's impression of state court activity in this area is generally not . supported by the facts.

Although union fines are generally enforced through the threat of expulsion, there are occasions where this tactic does not intimidate the disciplined member and the labor organization is compelled to seek court enforcement in a collection suit. ${ }^{149}$ The state tribunals will frequently consider the underlying reason for the union's disciplinary action before granting enforcement of the fine, ${ }^{150}$ but they often ignore the reasonableness of the punishment which has been meted out. ${ }^{151}$ Therefore, so long as

${ }^{146}$ NLRB v. Strong, 393 U.S. 357 (1969). See Linn v. Plant Guard Workers, Local 114, 383 U.S. 53 (1966); Carey v. Westinghouse Elec. Corp., 375 U.S. 261 (1964); Smith v. Evening News Ass'n, 371 U.S. 195 (1962); Charles Dowd Box Co. v. Courtney, 368 U.S. 502 (1962).

147412 U.S. at $76-77$.

${ }_{148}$ Id. at 76. See NLRB v. Allis-Chalmers Mfg. Co., 388 U.S. 175, 193 n.32 (1967).

149 See Atleson, supra note 33, at 697, 724; Christensen, supra note 33, at 269-70;

Note, Judicial Enforcement of Union Disciplinary Fines, 76 YALE L.J. 563 (1967).

${ }_{150}$ "Courts' responses to union discipline vary markedly, depending on the conduct

for which punishment is imposed." Summers, Courts, supra note 9, at 198.

${ }_{151}$ The limits which the courts have placed on union discipline seem to have no relation to the severity of the penalty imposed, but are instead governed by the conduct which the union has sought to punish and the procedure used for determining the member's guilt.

Id. 179. 
the labor organization in question has imposed the disciplinary fine for the violation of a legitimate union rule, many state courts will simply refuse to consider the disciplined member's plea that he is being forced to suffer unreasonable retribution. The Boeing decision will thus permit unions in those jurisdictions to utilize the threat of unreasonably burdensome punishment to restrain members from engaging in activities protected by the NLRA which might arguably be contrary to some union rule. Without the hope of Labor Board intervention to prevent the use of excessively onerous discipline, the possibility that members will be forced to forgo the exercise of express statutory rights is obviously quite real.

\section{B. Lack of Uniform Standards}

Even those union members who are fortunate enough to reside in jurisdictions whose tribunals will examine the reasonableness of disciplinary fines in collection actions will face impediments should they contemplate the exercise of protected rights which might conflict with union obligations. Due to the lack of consistency among courts of even the same state, individuals will be unable to predict how a tribunal would react to a penalty threatened by their union. The reason for these intrajurisdictional inconsistencies is explicable:

Faced with cases of unjust discipline, courts frequently give clauses in union constitutions a strained construction. Although, as a practical matter, the protection of members may sometimes be adequate, it does not result from established standards of fairness, but rather from state judges consciously preventing abuse of union discipline. Such result-oriented jurisprudence produces inconsistent rules and results and impairs predictability. A union member does not know what protections will be afforded him by a particular judge in a particular jurisdiction. ${ }^{152}$

Furthermore, due to the vastly different standards of reasonableness utilized by courts of different states, substantial inequities will be created for employees who exercise their NLRA rights in disregard of union warnings. "The courts, in deciding union discipline cases, have produced a bewildering tangle of inconsistent rules and results. This mass of contradictions is more than a difference of opinions among various courts, for a

152 Note, supra note 33 , at 1101. 
court will frequently evade even its own rules and * precedents." 153

This unpredictability renders it virtually impossible for an individual to calculate beforehand the amount of discipline which he might have to suffer should he undertake a particular course of action in violation of union rules. The likelihood that this unpredictability will compel him to refrain entirely from his contemplated action is clear. ${ }^{154}$ Furthermore, since the courts of different states utilize vastly divergent standards to determine the reasonableness of union fines, ${ }^{155}$ there is a very real possibility that members of the same union may suffer very different penalties for engaging in identical conduct. ${ }^{156}$ Such an inequitable situation would certainly be contrary to the frequently expressed desire for uniformity in national labor policy. ${ }^{157}$

\section{The Expense of Litigation}

Judicial protection against oppressive union discipline is meaningful only to the extent that effective remedies are practically available. Measuring the effectiveness of remedies in practical terms requires close scrutiny of ... the costs of litigation. ${ }^{158}$

When an individual files an unfair labor practice charge with the NLRB and that agency issues a complaint, the charging party is subsequently represented by the General Counsel's office at no expense to himself. Thus, were the issue of reasonableness cognizable before the Labor Board, disciplined union members would not have to forgo a challenge to an unreasonably excessive fine due to the fear of incurring substantial legal fees. However, under the Boeing decision, a disciplined member may only litigate the reasonableness question as a defense to a collection suit

${ }^{153}$ Summers, supra note 16, at 1050. See Summers, Courts, supra note 9, at 184: "[P]ast practice is ignored or rejected; and prior court decisions interpreting similar clauses are not precedents."

${ }^{154}$ The only manner in which such an individual could undertake the action he is considering without the fear of unreasonably excessive union discipline would be for him first to resign from the labor organization. See NLRB v. Granite State Joint Bd., Textile Workers Union, 409 U.S. 213 (1972). However, this would require him to forgo the right to participate in union affairs, and it might additionally mean the forfeiture of valuable monetary benefits, such as pension and welfare rights, which are perquisites of membership.

155 Atleson, supra note 33, at 716 .

156 Even though the union might well impose identical fines on all members who have engaged in the same activity, the divergence of state standards will cause some courts to enforce the entire fine, while others may either sustain a slightly reduced amount or require a substantial reduction as a prerequisite to collection.

157 Note, supra note 33, at 1102.

158 Summers, Courts, supra note 9, at 212. 
by his labor organization, and the expense of such recourse may be prohibitive.

Professor Summers' extensive study of union discipline has disclosed that many disciplined individuals never challenge the amount of union fines due to their inability to afford the necessary legal fees. ${ }^{159}$ They are wage earners who must finance their litigation out of what meager savings they have accumulated, while the adversary labor organization has a substantial treasury which permits it to utilize costly procedural maneuvers and extended appeals to exhaust the individual's resources. ${ }^{160}$ "The danger that the legal rights of a disciplined member will go by default because of the cost of asserting them in court is obvious ...."161 Therefore, absent the availability of Labor Board relief in cases of excessive discipline, labor organizations are left free to utilize unreasonably harsh measures to deter effectively the meaningful exercise of NLRA rights by their members. It is most doubtful that either the Taft-Hartley Congress or the AllisChalmers Court ever intended to permit such a negation of individual rights.

\section{A Suggested Approach \\ A. Labor Board Responsibility}

If the important individual rights which are expressly guaranteed by section 7 of the NLRA are to be protected against diminution through the imposition of excessively large union disciplinary fines, the reasonableness of such discipline must be subject to challenge in Labor Board unfair labor practice proceedings. Although the "[p]otential responsibility for examining the reasonableness of all fines is a frightening prospect to a Board which is already worried about its work load," 162 this should not negate the Labor Board's statutory obligation in this important area. "[P]articularly Scofield, as well as Allis-Chalmers and Marine Workers, admonishes the Board not to abdicate its responsibility to limit discipline which is offensive to public policy where penalties are involved." 163

${ }^{159}$ See id. 222: "The very fact that so few cases involve individuals unsupported by factional groups suggests that the lone member's rights go by default, and many lawyers frankly admitted that they would not take a case unless it was backed by a substantial group." See Summers, supra note 16, at 1095 .

${ }^{160}$ Summers, Courts, supra note 9 , at 221 .

161 Id. 220.

${ }^{162}$ Reasonableness of Fines, supra note 81, at 332 n.27. See Fanning, Can We Make the NLRB Work More Effectively?, 23 N.Y.U. Conf. ON LABOR 101 (1971). See also Atleson, supra note 33 , at 723 .

${ }^{163}$ Gould, supra note 33 , at 1137. 
The Labor Board has not evaluated the reasonableness of union disciplinary fines, but it has had experience with the reasonableness of union exactions in a related area. Under section $8(b)(5)$ of the NLRA, ${ }^{164}$ the NLRB is required to determine whether initiation fees required by labor organizations pursuant to union-security agreements are excessive. ${ }^{165}$ The fact that section $8(\mathrm{~b})(1)(\mathrm{A})$ does not provide the Labor Board with specific standards to be applied to determine the reasonableness of union disciplinary fines, while section $8(b)(5)$ does mention several standards, ${ }^{166}$ should not detract from the NLRB's responsibility under section 8(b)(1)(A). A previous Supreme Court decision concerning a related NLRA jurisdictional question stated:

It is true that this forces the Board to exercise . . . powers which are broad and lacking in rigid standards to govern their application. But administrative agencies are frequently given rather loosely defined powers to cope with problems as difficult as those posed by [unreasonable disciplinary fines.] . . . It has had long experience in hearing and disposing of similar labor problems. With this experience and a knowledge of the standards generally used by arbitrators, ... . [state tribunals,] and others in wrestling with this problem, we are confident that the Board need not disclaim the power given it for lack of standards. Experience and common sense will supply the grounds for the performance of this job which Congress has assigned to the Board. ${ }^{167}$

The Labor Board should establish standards of reasonableness which could be applied uniformly in all situations where disciplined union members challenge disciplinary fines as being unreasonably excessive. This would provide members of labor organizations with the ability to predict the consequences of contemplated behavior which might be violative of union rules,

16429 U.S.C. $\$ 158(b)(5)(1970)$ provides that it is an unfair labor practice for a union

(5) to require of employees covered by an agreement authorized under subsection (a)(3) of this section the payment, as a condition precedent to becoming a member of such organization, of a fee in an amount which the Board finds excessive or discriminatory under all the circumstances.

For the text of $\S 8(\mathrm{a})(3), 29$ U.S.C. \& 158(a)(3) (1970), see note 114 supra.

${ }_{165}$ See, e.g., Longshoremen, ILA, Local 1419, 186 N.L.R.B. 674 (1970) (violation of $\S$ 8(b)(5)). See also NLRB v. Television Employees, Local 804, 315 F.2d 398 (3d Cir. 1963).

${ }_{166}$ See NLRB v. Boeing Co., 412 U.S. 67, 75 n.10 (1973).

${ }_{167}$ NLRB v. Radio Eng'rs Union, 364 U.S. 573, 583 (1961). Although this case dealt specifically with the duty of the Labor Board to resolve jurisdictional disputes under $\S 10(\mathrm{k})$ of the NLRA, 29 U.S.C. $\$ 160(\mathrm{k})(1970)$, its reasoning is appropriate to the reasonableness issue. Cf. Getman \& Goldberg, The Myth of Labor Board Expertise, $39 \mathrm{U}$. ChI. L. Rev. 681 (1972). 
and it would obviate the present practice of having the enforceability of such fines be dependent upon the vagaries of state law. It would also provide state and federal courts with a set of uniform standards which they could apply in collection actions to determine the reasonableness issue, should such tribunals be granted concurrent jurisdiction with the Labor Board. ${ }^{168}$

\section{B. Standards of Reasonableness}

Although no attempt will be made here to discuss the infinite variety of situations which may involve union disciplinary fines, a few brief comments concerning appropriate standards of reasonableness are relevant. The District of Columbia Circuit noted some pertinent limitations in its Booster Lodge decision: ${ }^{169}$

The Board must remember that a fine imposed for the violation of a legitimate union rule should be viewed as presumptively protective, and therefore privileged, when the amount of the fine, taking into account the character and importance of the ends served by the rule being enforced, is reasonably related to the need for protection. On the other hand, if the amount of the fine is such as to be inordinately disproportionate to the needed protection, an inference is warranted that the . fine was imposed upon the member, not in vindication of a legitimate union interest, but rather as a reprisal for his having exercised a statutorily protected right. In the latter situation, . . . the fine would be "coercive" within the meaning of Section $8(\mathrm{~b})(1)(\mathrm{A})$ of the Act.

When the Taft-Hartley Congress amended the NLRA, it and the courts were operating under the theory that a contractual relationship defines the obligations which exist between a member and his labor organization. ${ }^{170}$ Since an action to collect a fine is generally premised upon contractual principles, the abhorrence of contract law for penalties ${ }^{171}$ should be considered. If a disciplinary fine is clearly retributive, rather than compen-

${ }^{168}$ It would also establish uniform standards which arbitrators could utilize in cases deferred to them by the Labor Board under the Collyer doctrine. See Nabisco, Inc. v. NLRB, 479 F.2d 770 (2d Cir. 1973); Coglyer Insulated Wire, 192 N.L.R.B. 837 (1971). See also Revised Memorandum of NLRB General Counsel Nash on Arbitration Deferral Policy Under Collyer, 4 CCH LAB. L. REP.-LAB. REL. T 9031 (1973). See generally Johannesen \& Smith, Open Sesame to Deferral, 23 LAB. L.J. 723 (1972); Note, The NLRB's Arbitration Deferral Policy Under Collyer: The Impact of National Radio Co., 53 B.U.L. REv. 711 (1973).

169 Booster Lodge 405, IAM v. NLRB, 459 F.2d 1143 , 1159 (D.C. Cir. 1972), rev'd sub nom. NLRB v. Boeing Co., 412 U.S. 67 (1973).

${ }_{170}$ NLRB v. Allis-Chalmers Mfg. Co., 388 U.S. 175, 182 (1967); Machinists v. Gonzales, 356 U.S. 617,618 (1958). See Summers, Courts, supra note 9, at 180; Note, supra note 33 , at 1100 .

1715 A. Corbin, Contracts $\$ \$ 1055-58$ (2d ed. 1954); 3 S. Williston, A Treatise oN THE LAW OF CoNTRACTS $\$ 776$ (rev. ed. 1936). 
satory or rehabilitative, it should not receive NLRB approval, but should rather be struck down as violative of section $8(\mathrm{~b})(1)(\mathrm{A}){ }^{172}$

The most common circumstances involving the threat of court-enforced disciplinary fines concern the situation in which union members have crossed picket lines to work during an authorized economic strike. Although the trial examiner in the Booster Lodge case ${ }^{173}$ attempted to resolve all of the conflicting policy considerations in this area by devising a formula whereunder a union fine covering no more than thirty-five percent of a strikebreaker's straight-time wage earnings and eighty percent of his overtime or premium pay would be presumptively reasonable, such a rigid test based almost entirely upon the trial examiner's own visceral reaction to the strikebreaking situation should be rejected. It simply has no support, either in the statute itself, or in its legislative history. The only absolute limitation which can be supported by resorting to the provisions of the NLRA is one premised upon the rationale that any disciplinary fine which exceeds the net earnings derived by the strikebreaker, less any union strike benefits or general welfare payments he would have received had he honored the work stoppage, should be considered to be conclusively unreasonable. This restriction is based upon the principles which are clearly enunciated in sections $8(\mathrm{a})(3)$ and $8(\mathrm{~b})(2)$ of the NLRA, ${ }^{174}$ which prohibit any interference by a labor organization with the employment status of any member, except where he has failed to tender his dues and fees pursuant to a valid union-security agreement. ${ }^{175}$ Since a union fine which exceeds the net benefits obtained by a member on account of his strikebreaking is tantamount to a post-strike work suspension to the extent the fine exceeds such net earnings, ${ }^{176}$ this would violate the congressional concerns underlying the enactment of sections $8(\mathrm{~b})(2)$ and $8(\mathrm{a})(3) .{ }^{177}$

${ }^{172}$ See Tri-Rivers Marine Engr's Union, 189 N.L.R.B. 838 (1971); International Molders, Local 125, 178 N.L.R.B. 208 (1969), enforced, 442 F.2d 92 (7th Cir. 1971). See also notes 43-51 supra \& accompanying text.

${ }_{173}$ Booster Lodge No. 405, IAM, 185 N.L.R.B. 380 (1970).

${ }^{174}$ See note 114 supra. See also Scotield v. NLRB, 394 U.S. 423, 428 (1969); NLRB v. Allis-Chalmers Mfg. Co., 388 U.S. 175, 195 (1967).

${ }^{175}$ See notes 114-19 supra \& accompanying text.

176 See Gould, supra note 33, at 1090 .

177 Booster Lodge 405, IAM v. NLRB, 459 F.2d 1143, 1159 \& n.38 (D.C. Cir. 1972), rev'd sub nom. NLRB v. Boeing Co., 412 U.S. 67 (1973). Although the excessive fine situation does not fit within the express coverage of $\S 8(\mathrm{~b})(2)$ since the union is not inducing the employer to discriminate against the employee, this should not prevent the application of the principles underlying $\S \S 8(\mathrm{~b})(2)$ and $8(\mathrm{a})(3)$, which the Allis-Chalmers and Scofield decisions both recognized. See Scofield v. NLRB, 394 U.S. 423, 428 (1969); NLRB v. Allis-Chalmers Mfg. Co., 388 U.S. 175, 195 (1967).

This suggested limitation comports with the approach which Professors Bok and Dunlop have proposed. D. BoK \& J. DunLOP, LABOR AND THE AMERICAN Community $106-07$ (1970). See also Gould, supra note 33, at 1124 . 
Within this absolute limit, the Labor Board should have no difficulty in devising an appropriate set of standards to resolve reasonableness questions. This issue should be determined in particular cases with reference to the specific circumstances leading to the imposition of the disciplinary fine. The relative strength of the labor organization involved and the detrimental effect of the member's violation upon the effectiveness of the union as an institution should be considered, along with the amount of gain, if any, realized by the offending member. The availability of other effective remedies which would not impose such a severe hardship as a fine would also be pertinent. Of course, there are many other similar factors relevant to the reasonableness issue, but the NLRB is clearly cognizant of them and capable of developing more specifically the standards in this area once it has reconsidered its prior conclusion. ${ }^{178}$

\section{The Preemption Question}

Should the Labor Board accept jurisdiction over the reasonableness issue, an important question of federal preemption would arise. The courts would have to determine the extent to which state and federal tribunals ${ }^{179}$ would be ousted from jurisdiction.

Under the Garmon preemption doctrine, "[w]hen it is clear or may fairly be assumed that the activities which a State purports to regulate are protected by $\S 7$ of the National Labor Relations Act, or constitute an unfair labor practice under $\S 8$, due regard for the federal enactment requires that state jurisdiction must yield." ${ }^{180}$ Since it is urged here that the NLRB accept jurisdiction over the reasonableness issue under its section $8(\mathrm{~b})(1)(\mathrm{A})$ authority, thus rendering this question "arguably subject to $\S 7$ or $\S 8$ of the Act, the States as well as the federal courts [would have to] defer to the exclusive competence of the National Labor Relations Board . . .,"181 unless countervailing considerations militate against preemption.

Despite the broad reach of its preemption doctrine, the

${ }^{178}$ But see Getman \& Goldberg, supra note 167.

179 Federal courts would only be able to hear union collection suits where the diversity jurisdiction prerequisites were satisfied. 28 U.S.C. $\S 1332(1970)$. The $\$ 10,000$ jurisdictional minimum would probably preclude federal court jurisdiction in most instances.

180 San Diego Bldg. Trades Council v. Garmon, 359 U.S. 236, 244 (1959). See generally notes $136-46$ supra \& accompanying text.

${ }_{181} 359$ U.S. at 245. See Motor Coach Employees v. Lockridge, 403 U.S. 274 (1971). See also Weber v. Anheuser-Busch, Inc., 348 U.S. 468, 480-81 (1955); Garner v. Teamsters Union, 346 U.S. 485, 490-91 (1953). 
Garmon Court recognized that state tribunals need not yield exclusive jurisdiction to the Labor Board "where the regulated conduct touche[s] interests so deeply rooted in local feeling and responsibility that, in the absence of compelling congressional direction, we could not infer that Congress had deprived the States of the power to act." ${ }^{182}$ It is clear that many state tribunals have been adjudicating internal union disputes for more years than the NLRB has been in existence. ${ }^{183}$ This traditional concern of state tribunals was expressly noted in the Allis-Chalmers decision. ${ }^{184}$ Under these circumstances, the "traditional state concern" exception to the Garmon preemption doctrine should be utilized to permit state courts to exercise concurrent jurisdiction with the Labor Board over the question of reasonableness of union fines. ${ }^{185}$

The propriety of union disciplinary fines should not be dependent upon the vagaries of state law, but should rather be determined by clear standards promulgated by the Labor Board. ${ }^{186}$ The application of such uniform NLRB standards in state court collection suits would insure that the proper balance which the Labor Board draws between protected individual rights and the right of labor organizations to regulate their internal affairs will be preserved. Furthermore, the establishment of such a uniform set of standards which would be applied in both NLRB and state court proceedings would satisfy the frequently expressed Supreme Court prerequisite to the applicability of one of the Garmon preemption exceptions: that state tribunals apply federal substantive law. ${ }^{187}$

Once a relatively complete set of uniform reasonableness standards has been promulgated by the NLRB and upheld by the federal courts, there should be no necessity for state courts to defer to the specific labor expertise and competence of the Labor

182 San Diego Bldg. Trades Council v. Garmon, 359 U.S. 236, 243-44 (1959).

${ }^{183}$ Summers, Courts, supra note 9; Summers, supra note 16. See also NLRB v. Boeing Co., 412 U.S. 67, 75 (1973).

${ }_{184}$ See NLRB v. Allis-Chalmers Mfg. Co., 388 U.S. 175, 193 n.32 (1967).

185 Gould, supra note 33, at 1133-34; Reasonableness of Fines, supra note 81, at 333-35.

This concurrent jurisdictional approach would be analogous to similar exceptions to the Garmon doctrine which the Supreme Court has recognized. See, e.g., Vaca v. Sipes, 386 U.S. 171 (1967) (duty of fair representation); Linn v. Plant Guard Workers, Local 114,383 U.S. 53 (1966) (defamation); Carey v. Westinghouse Elec. Corp., 375 U.S. 261 (1964) (arbitration); Smith v. Evening News Ass'n, 371 U.S. 195 (1962) (breach of contract). 1103-07.

${ }^{188}$ See notes $153-57$ supra \& accompanying text. See also Note, supra note 33 , at ${ }_{187}$ See, e.g., Vaca v. Sipes, 386 U.S. 171, 174 (1967); Linn v. Plant Guard Workers, Local 114, 383 U.S. 53, $64-65$ (1966); Carey v. Westinghouse Elec. Corp., 375 U.S. 261 (1964); Smith v. Evening News Ass'n, 371 U.S. 195 (1962); Charles Dowd Box Co. v. Courtney, 368 U.S. 502 (1962). . 
Board ${ }^{188}$ with respect to ordinary reasonableness questions. In this area, the existence of pervasive reasonableness standards would obviate the necessity for deferral by state courts to the primary jurisdiction of the NLRB, since resolution of the reasonableness issues covered by such standards would not involve questions beyond the conventional experience of judges nor concern determinations requiring particular expertise in the area of labor law. ${ }^{189}$ However, different considerations would be involved when state courts are presented with unusual reasonableness questions.

Where a reasonableness issue is raised in a state court collection action which cannot practically be resolved through the direct application of established Labor Board standards, or which requires the consideration of peculiar labor relations problems which are not ordinarily within the general competence of trial judges, state tribunals should defer to the primary jurisdiction of the NLRB whenever possible. ${ }^{190}$ This would insure the resolution of difficult questions by the federal agency which Congress created to administer the NLRA. Nevertheless, there may be instances where state court adjudication of such complex or novel issues would be necessary.

Section $10(\mathrm{~b})$ of the NLRA ${ }^{191}$ expressly provides that the Labor Board only has jurisdiction over unfair labor practice charges which are filed within six months after they arise. Since a state statute of limitations may permit the commencement of a fine collection action by a labor organization two, three or four years subsequent to the imposition of the discipline involved, it is

${ }^{188} \mathrm{Cf}$. Getman \& Goldberg, supra note 167.

${ }^{189}$ Cf. Local 189, Meat Cutters v. Jewel Tea Co., 381 U.S. 676, 684-85 (1965) (citations omitted):

The doctrine of primary jurisdiction ... applies where a claim is originally cognizable in the courts, and comes into play whenever enforcement of the claim requires the resolution of issues which, under a regulatory scheme, have been placed within the special competence of an administrative body . . . . The doctrine is based on the principle "that in cases raising issues of fact not within the conventional experience of judges or cases requiring the exercise of administrative discretion, agencies created by Congress for regulating the subjeco matter should not be passed over," and "requires judicial abstention in cases where protection of the integrity of a regulatory scheme dictates preliminary resort to the agency which administers the scheme."

See also Federal Maritime Bd. v. Isbrandtsen Co., 356 U.S. 481 (1957); Far East Conference v. United States, 342 U.S. 570 (1952). See generally Jaffe, Primary Jurisdiction, 77 Harv. L. Rev. 1037 (1964); Meltzer, supra note 137.

${ }_{190}$ A deferring state court should probably retain the collection action on its docket pending resolution of the reasonableness question by the Labor Board. It could thereafter adjudicate the remaining issues in the collection suit. El Dorado Oil Works v. United States, 328 U.S. 12, 17 (1946); General Am. Tank Car Corp. v. El Dorado Terminal Co., 308 U.S. 422, 432-33 (1940).

19129 U.S.C. \$ $160($ b) (1970). 
apparent that a state tribunal may well be presented with a situation where deferral to the special competence of the NLRB would be appropriate but for the fact that the Labor Board's six month limitation period had expired prior to the institution of the state court suit. ${ }^{192}$ Under such circumstances, the state court could dismiss the entire collection action, enforce the fine imposed without considering its reasonableness, or itself resolve the novel reasonableness issue. Since it would not be fair to penalize the labor organization which has commenced its collection suit within the applicable statute of limitations period by dismissing its enforcemeno action, and it would certainly not be appropriate to ignore the rights of the disciplined individual by enforcing the fine in toto, the state tribunal should attempt to resolve the reasonableness question through analogy to available federal standards. ${ }^{193}$ This should not create too much dissonance in the reasonableness area, and it would permit labor organizations to enforce reasonable disciplinary measures pursuant to the congressional intent evidenced by the proviso to section $8(\mathrm{~b})(1)(\mathrm{A})$. At the same time it would respect the correlative section $8(\mathrm{~b})(1)(\mathrm{A})$ protection of individual rights. This would certainly be the best means of resolving a difficult problem, and it would generally recognize and protect the competing federal interests involved.

\section{ConClusion}

In its recent Boeing decision, the Supreme Court held that the reasonableness of union disciplinary fines is not relevant to a section $8(\mathrm{~b})(1)(\mathrm{A})$ unfair labor practice proceeding. The Court indicated its belief that the Labor Board should not interfere with the traditional activity of state courts in this area, and it rejected the implications arising from prior Supreme Court dicta concerning this issue.

The Boeing holding ignores the impermissibly detrimental effect which unreasonably large union fines may have upon the exercise of section 7 rights, and it further fails to consider the important federal labor policies evidenced by sections $8(a)(3)$ and $8(\mathrm{~b})(2)$ and the fair representation doctrine. The Boeing Court also relied upon equivocal legislative history to accomplish the

192 Since a disciplined union member would generally not fear a fine until the threat of enforcement became real through the institution of a collection suit, it is apparent that it would not usually be until this time that an unfair labor practice charge would be filed with the NLRB.

${ }^{193} \mathrm{Cf}$. Gould, supra note 33 , at $1134-36$. 
exact "reverse preemption" proscribed by section 10 (a) of the NLRA and denounced in prior federal labor preemption decisions of the Supreme Court.

The reasonableness question should be cognizable before the NLRB in appropriate unfair labor practice proceedings. This would prevent unwarranted interference by labor organizations with protected individual rights, while recognizing the established authority of unions to impose and enforce reasonable disciplinary measures in vindication of legitimate internal union regulations. This suggested approach would also protect individual union members who lack the financial resources to litigate the reasonableness issue in state court collection suits, and it would ameliorate the present situation whereunder state tribunals either ignore the reasonableness question or resolve it through the application of contradictory and unpredictable state standards.

State tribunals should not be preempted from jurisdiction over the issue of the reasonableness of union fines because of the proposed Labor Board authority in this area. They should instead be permitted to exercise concurrent jurisdiction, due to the traditional concern of many state courts with respect to this issue. The state forums should, however, be required to apply the uniform standards which the Labor Board promulgates for resolving reasonableness questions. This would guarantee adequate protection for federally created individual and union rights, while recognizing the traditional authority of state tribunals over disputes involving internal union matters. This approach would also be consistent with prior Supreme Court decisions regarding the preemption doctrine in the area of labor law. 